Rev. Int. Contam. Ambie. 37, 237-247, 2021

https://doi.org/10.20937/RICA.54145

\title{
EFFECT OF COVID-19 LOCKDOWN ON AIR QUALITY IN URBAN AND SUBURBAN AREAS OF EXTREMADURA, SOUTHWEST SPAIN: A CASE STUDY IN USUALLY LOW POLLUTED AREAS
}

Efecto del confinamiento de la Covid-19 sobre la calidad del aire en zonas urbanas y suburbanas de Extremadura, suroeste de España: un caso de estudio en zonas habitualmente poco contaminadas

$$
\text { Maria CERRATO-ALVAREZ }{ }^{1 *} \text {, Conrado MIRÓ-RODRÍGUEZ }{ }^{2} \text { and Eduardo PINILLA-GIL }{ }^{1}
$$

${ }^{1}$ Departmento de Química Analítica y IACYS, Universidad de Extremadura, Av. de Elvas, s/n, 06006 Badajoz, Spain.

${ }^{2}$ Departmento Física Aplicada, Universidad de Extremadura, Av. de la Universidad, s/n, 10071 Cáceres, Spain.

*Author for correspondence: macerratoa@unex.es

(Received: October 2020; accepted December 2020)

Key words: SARS-CoV-2, air pollutants, Spain, $\mathrm{NO}_{2}, \mathrm{O}_{3}, \mathrm{BTX}$.

\begin{abstract}
Lockdown measures were established in Spain from $14^{\text {th }}$ March 2020, to flatten the pandemic curve of coronavirus disease (COVID-19). The increasingly stringent implementation of these measures has made it possible to assess the effect of anthropogenic activities on the most relevant air pollutants present in ambient air. Whereas most published reports focus on highly polluted urban areas, the present work aims to quantify variations in the levels of $\mathrm{NO}_{2}, \mathrm{O}_{3}$ and BTX (benzene, toluene and xylene) due to the COVID-19 lockdown in usually low polluted urban and suburban areas within Extremadura (Spain). Compared to the reference period from 2010 to 2019, significant reductions in $\mathrm{NO}_{2}$ levels occurred in the suburban stations of Badajoz, Cáceres, Mérida, Plasencia and Zafra $(-50.4 \%,-71.6 \%,-55.2 \%,-64.6 \%$ and $-51.8 \%$, respectively), likely due to the limitation of road traffic as the primary source of nitrogen oxides (NOx). These percentages of reduction are similar to data reported in high polluted areas. Similarly, $\mathrm{O}_{3}$ levels have decreased slightly by $-9.9 \%$ in Badajoz, $-9.5 \%$ in Mérida and $-18.2 \%$ in the Monfragüe National Park. The reduction in $\mathrm{O}_{3}$ levels may be due to a decrease in NOx limiting atmospheric conditions and the influence of weather conditions (high cloudiness and rainy days) during the lockdown period. No defined trend was observed for VOCs (BTX), probably due to the very low levels of these contaminants, close to the detection limit both during the lockdown and the reference periods.
\end{abstract}

Palabras clave: SARS-CoV-2, contaminantes del aire, España, $\mathrm{NO}_{2}, \mathrm{O}_{3}$, BTX.

\section{RESUMEN}

En España se establecieron medidas de confinamiento a partir del 14 de marzo de 2020, para aplanar la curva de la pandemia de la enfermedad del coronavirus (COVID-19). La aplicación de estas medidas, cada vez más estricta, ha permitido evaluar el efecto de las actividades antrópicas en los contaminantes atmosféricos más relevantes presentes 
en el aire ambiente. Mientras que la mayoría de los trabajos publicados se centran en zonas urbanas altamente contaminadas, el presente trabajo tiene como objetivo cuantificar las variaciones en los niveles de $\mathrm{NO}_{2}, \mathrm{O}_{3}$ y BTX (benceno, tolueno y xileno) debido al confinamiento de la COVID-19 en zonas urbanas y suburbanas habitualmente poco contaminadas dentro de Extremadura (España). En comparación con el período de referencia de 2010 a 2019, se produjeron reducciones significativas de los niveles de $\mathrm{NO}_{2}$ en las estaciones suburbanas de Badajoz, Cáceres, Mérida, Plasencia y Zafra $(-50.4 \%,-71.6 \%,-55.2 \%,-64.6 \%$ y $-51.8 \%$, respectivamente), probablemente debido a la limitación del tráfico rodado como principal fuente de óxidos de nitrógeno (NOx). Estos porcentajes de reducción son similares a los datos registrados en las zonas de alta contaminación. Asimismo, los niveles de $\mathrm{O}_{3}$ han disminuido ligeramente en un $-9.9 \%$ en Badajoz, un $-9.5 \%$ en Mérida y un $-18.2 \%$ en el Parque Nacional de Monfragüe. La reducción de los niveles de $\mathrm{O} 3$ puede deberse a una disminución de las condiciones atmosféricas que limitan el NOx y a la influencia de las condiciones meteorológicas (alta nubosidad y días de lluvia) durante el período de confinamiento. No se observó ninguna tendencia definida para los COVs (BTX), probablemente debido a los niveles muy bajos de estos contaminantes, cercanos al límite de detección tanto durante el confinamiento como durante el período de referencia.

\section{INTRODUCTION}

In December 2019, an infectious disease producing severe acute respiratory syndrome was reported in Wuhan, China. A novel coronavirus caused the disease, so WHO assigned the name COVID-19 to the upcoming health threat (Saadat et al. 2020). Later, this infectious disease has spread to other countries to become a pandemic event (Muhammad et al. 2020). By the end of February 2020, the first cases of COVID-19 were reported in Spain (Tobías et al. 2020). Since then to $12^{\text {th }}$ November 2020, 1417709 people have been infected in Spain (Hopkins 2020) and 40105 people have died due to COVID-19 (Global Change Data Lab 2020), making Spain the third European country in deaths after Italy and France. Lockdown measures in Spain entered into force on $14^{\text {th }}$ March 2020 (Ministerio de la Presidencia, Relaciones con las Cortes y Memoria Democrática 2020a). These measures included social estrangement, restricted mobility unless necessary to reach workplaces or other essential needs, reduction of working hours, closure of restaurants, shops and schools, interruption of public road and air transport, obligatory use of face masks, among others. From $30^{\text {th }}$ March 2020, stricter restrictions were imposed, including the total closure of non-essential industrial activities (Ministerio de la Presidencia, Relaciones con las Cortes y Memoria Democrática 2020b). Confinement due to COVID-19 has harmed the social life and economic activity but also resulted in significantly reduce pollution levels in urban air (Muhammad et al. 2020). Lockdown measures was relaxed from $29^{\text {th }}$ June 2020.
Recent work has reported improvements in air quality, mainly due to reduced transport activities. Substantial $\mathrm{NO}$ and $\mathrm{NO}_{2}$ reductions, compared to the reference period 2017 to 2019 , have been recorded at traffic stations in Nice (-88.1 and 68.9\%), Rome $(-70.5$ and $55.1 \%)$ and Valencia ( -75.5 and $-70.6 \%)$. There were also slight decreases in particulate levels $\left(\mathrm{PM}_{10}\right.$ and $\left.\mathrm{PM}_{2.5}\right)$ in Nice (-7.6 and 8.0 \%) and Rome $(-3.0$ and $-1.5 \%)$, and a more substantial decrease in Valencia (-51.3 and $-29.3 \%$ ) (Sicard et al. 2020). Tobías et al. (2020) observed significant reductions of $\mathrm{NO}_{2}(-51 \%), \mathrm{PM}_{10}(-28 \%)$ and black carbon (BC) $(-45 \%)$, compared to the month before confinement, at a traffic station in Barcelona. Nakada and Urban (2020) reported drastic reductions in NO (up to $-77.3 \%$ ), $\mathrm{NO}_{\mathrm{x}}$ (up to $-54.3 \%$ ) $\mathrm{CO}$ (up to $-64.8 \%$ ) during the lockdown, relative to the monthly average of five previous years, in the Sao Paulo urban area. Muhammad et al. (2020) collected $\mathrm{NO}_{2}$ data from satellite monitoring instruments (SATELLITEAURA and Sentinel-5P) and observed decreases of up to -30 $\%$ in countries such as Spain, Italy, France, China and the USA. Decreases in the levels of certain pollutants in these studies (NO, $\left.\mathrm{NO}_{2}, \mathrm{PM}, \mathrm{BC}, \mathrm{CO}\right)$ are coincident with increases in $\mathrm{O}_{3}$ levels. These results are related to the decrease of nitrogen oxide emissions that reduces the consumption of $\mathrm{O}_{3}$ from the reaction: $\mathrm{NO}+\mathrm{O}_{3} \rightarrow \mathrm{NO}_{2}+\mathrm{O}_{2}$ (Tobías et al. 2020).

Most published studies on the effect of confinement on air quality levels relate to urban and industrial areas in large cities, where limit values for the protection of human health are frequently exceeded. Most of them compare the confinement period with 
the equivalent period of 2019 , and even some compare with the immediate pre-lockdown period of 2020. In this work, our goal is to complete and expand the information available by assessing air quality during the period of confinement in suburban areas of small towns and rural areas of the Extremadura, Spain, where air pollution levels are usually low. Specifically, our goal was to quantify the effect of confinement due to COVID-19 at $\mathrm{NO}_{2}, \mathrm{O}_{3}$ and benzene, toluene, xylene (BTX) levels, comparing the lockdown period with the equivalent period of the previous ten years (2010-2019), to minimise the influence of seasonal variability of the concentrations of the pollutants studied.

\section{MATERIALS AND METHODS}

\section{Study area and data collection}

Extremadura is located in the southwest of the Iberian Peninsula, bordering Portugal, with an area of $41634 \mathrm{~km}^{2}$, approximately $8 \%$ of the total area of Spain. It is divided into two provinces: Badajoz and Cáceres, and has 1067710 inhabitants, making it one of the least populated areas. About $30 \%$ of the inhabitants are concentrated in the cities of Badajoz, Cáceres and Mérida, so Extremadura can be considered predominantly rural.

The primary sector has a significant weight in the economy of Extremadura, being one of the largest producers of tabacco. Most of the industries present are linked to agriculture. Due to its climatic conditions, renewable energy is notable, with photovoltaic energy being the most important. Therefore, the economy of this region depends largely on its natural resources (Sánchez-Martín et al. 2019). A large part of the population in this region is employed in the service sector (approximately $60 \%$ ), which is concentrated in Badajoz, Cáceres, Mérida and Plasencia. The main transport network in this region is by road, as it lacks a rail network and quality airport.

The air quality in the low industrialized and scarcely populated Extremadura is usually good, except by frequent ozone episodes in the summer season, mainly related to climatic conditions (high temperatures and intense solar radiation) (CerratoAlvarez et al. 2020). African dust outbreaks are also frequent in Extremadura, contributing significantly to increased levels of particulate matter (Querol et al. 2019).

This study includes five cities within the Extremadura region (Fig. 1): Badajoz (BA, 38 $53^{\circ}$ ' 12" N and $6^{\circ} 58^{\prime} 15^{\prime \prime} \mathrm{W}, 1,444 \mathrm{~km}^{2}, 150702$ inhabitants), Cáceres (CC, 39 29' $01^{\prime \prime} \mathrm{N}$ and $6^{\circ} 20^{\prime} 37^{\prime}$ ' W, $1,754 \mathrm{~km}^{2}, 96126$ inhabitants), Mérida (MR, 38 $34^{\circ}$ ' $23^{\prime \prime} \mathrm{N}$ and $6^{\circ} 20^{\prime} 18^{\prime \prime} \mathrm{W}, 867.2 \mathrm{~km}^{2}, 59335$ inhabitants), Plasencia (PL, $40^{\circ} 02^{\prime} 37^{\prime \prime} \mathrm{N}$ and $6^{\circ} 05^{\prime} 09^{\prime \prime} \mathrm{W}$, $217.9 \mathrm{~km}^{2}, 39913$ inhabitants) and Zafra (ZF, 38 $25^{\circ}$ ' $41^{\prime \prime} \mathrm{N}$ and 6 $6^{\circ} 23$ ' 50 " W, $62.6 \mathrm{~km}^{2}, 16797$ inhabitants). Also, we studied the National Park of Monfragüe (MF, 39 $50^{\prime} 37^{\prime \prime} \mathrm{N}$ and $5^{\circ} 56^{\prime} 30^{\prime \prime} \mathrm{W}, 1,950 \mathrm{~km}^{2}$, unpopulated rural area) as a natural background
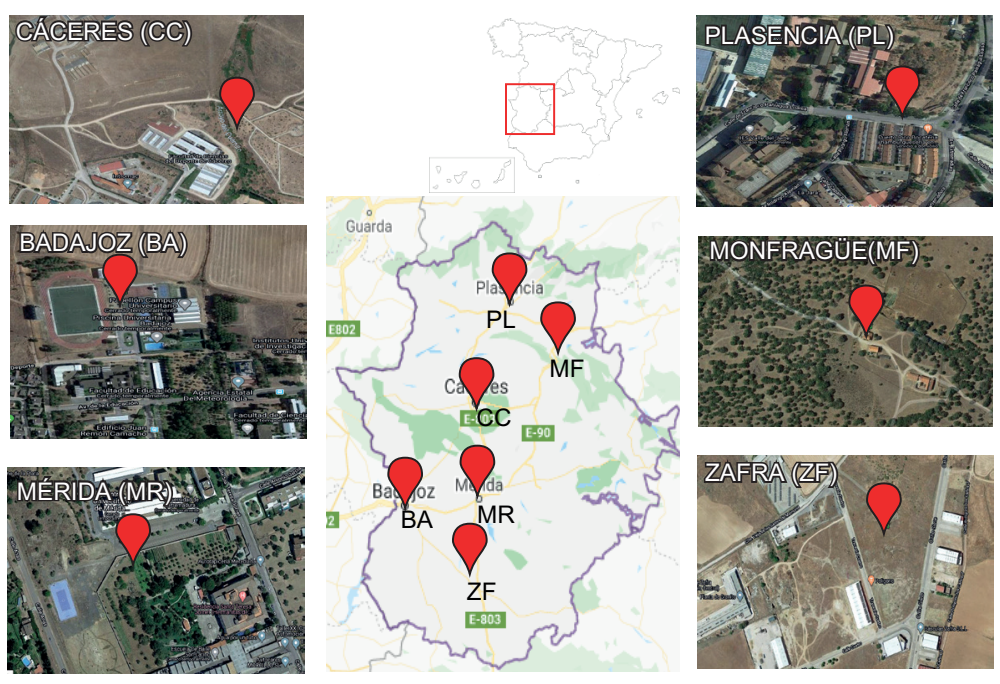

Fig. 1. Location of air quality monitoring stations in Extremadura. BA: Badajoz; CC: Cáceres; MR: Mérida; PL: Plasencia; ZF: Zafra; MF: Monfragüe National Park. 
environment. It should be noted that in the environments studied there are no pollution sources due to industrial activities.

The pollutant levels were measured at monitoring units located in suburban areas (BA, CC, MR, PL and ZF) and a rural area (MF), belonging to the Air Quality Monitoring Network of Extremadura, using methods and equipment that are routinely calibrated and maintained following the standard protocols established by the European Union's air quality monitoring networks for $\mathrm{NO}_{2}$ (European Committee for Standardization 2012a), for $\mathrm{O}_{3}$ (European Committee for Standardization 2012b) and for benzene (European Committee for Standardization 2015). The units measure $\mathrm{NO}_{2}$ by chemiluminescence analyzers Model 49i-B3ZAA (Thermo), $\mathrm{O}_{3}$ by UV photometric analyzers Model 42i-BZMTPAA (Thermo) and BTX by gas chromatography on a Model GC955 (SYNSPEC), Model 8610-C (SRI) and Model GC5000 (AMA). The total concentration of BTX was obtained as total carbon by adding the concentrations of benzene, toluene and xylene expressed as carbon. Concentrations of pollutant levels are measured under standard temperature and pressure conditions (293 K, $1 \mathrm{~atm}$ ). The Spanish Agency of Meteorology (AEMET) provided meteorological data (temperature, relative humidity, solar radiation, wind speed and wet precipitation) measured at the same locations or close to the air quality monitoring units.

\section{Definition of periods for statistical analysis}

Our statistical analysis considers daily average meteorological data and pollutant levels during four defined periods. The lockdown data (period 1, LDD) were collected from $15^{\text {th }}$ March to $15^{\text {th }}$ April 2020. The immediate pre-lockdown data (period 2, PLD) was set from $14^{\text {th }}$ February to $14^{\text {th }}$ March 2020 . A long-term lockdown reference period data (period 3 , LRD) was set from $15^{\text {th }}$ March to $15^{\text {th }}$ April for the years 2010 to 2019. A long-term pre-lockdown reference period data (period 4, PRD) was set from $14^{\text {th }}$ February to $14^{\text {th }}$ March for the years 2010 to 2019. The days without data were removed from the analysis. We used the Mann-Whitney nonparametric test to evaluate statistically significant differences because most of the data sets showed a non-normal distribution (Shapiro Wilk test, p-value $<0.05$ ).

\section{RESULTS AND DISCUSSION}

\section{Meteorological parameters}

We first inspected the existence of statistical differences among meteorological parameters measured during the 2020 lockdown period (LDD) and the 2010-2019 lockdown reference period (LRD), since these meteorological parameters have a considerable influence on the generation, evolution and distribution of the air pollutants under study. Specifically, temperature and relative humidity play an important role in the formation of tropospheric ozone, and solar radiation levels strongly influence both parameters. As shown in Table SI, temperature levels during LDD are not statistically different from the data registered during LRD ( $p$-value > 0.05, Mann-Whitney test). Solar radiation levels were significantly lower during LDD compared to LRD in BA $(-30.8 \%, \mathrm{p}=$ $0.02)$ and $\mathrm{CC}(-32.0 \%, \mathrm{p}=0.01)$, data from the rest of locations were not available. In contrast, relative humidity levels were significantly higher during LDD $(\mathrm{p}<0.0001$ in BA, CC, MF, PL and ZF; $p=0.002$ in MR), with increments of $+11.3 \%,+17.8 \%,+9.2 \%$, $+12.3 \%, 22.4 \%$ and $+12.1 \%$ in BA, CC, MR, MF, $\mathrm{PL}$ and $\mathrm{ZF}$, respectively. Wind speed was significantly lower during LDD compared to LRD $(\mathrm{p}<0.05)$ in BA and MR ( $-24.4 \%$ and $-20.0 \%$, respectively). In addition to the period of confinement, more specifically during the closure of the confinement, days with heavy rainfall have been recorded in the study area (maximum of $37.8 \mathrm{~mm}$ in $\mathrm{BA}$ ), resulting in significant increases $(\mathrm{p}$-value $=0.03$ and $\mathrm{p}$-value $=$ 0.02 ) compared to the average of previous years in PL and ZF ( $+46.8 \%$ and $+104.3 \%$, respectively).

\section{Nitrogen dioxide $\left(\mathrm{NO}_{2}\right)$}

Figure 2 presents the comparison of $\mathrm{NO}_{2}$ levels during the 2010-2019 lockdown reference period (LRD) and 2020 lockdown period (LDD). Absolute

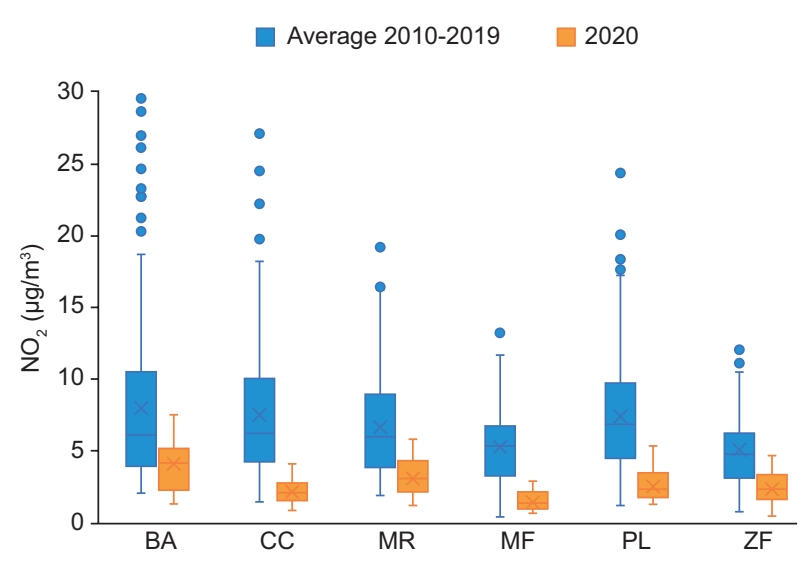

Fig. 2. Distribution of daily averages of $\mathrm{NO}_{2}$ during $\mathrm{LDD}\left(15^{\text {th }}\right.$ March to $15^{\text {th }}$ April 2020) and LRD (15 $5^{\text {th }}$ March to $15^{\text {th }}$ April 2010-2019). 
and percentage variations are presented in Table $\mathbf{I}$. $\mathrm{NO}_{2}$ shows a significant $(\mathrm{p}<0.0001)$ decrease during the lockdown in the locations studied, namely BA $(-50.4 \%), \mathrm{CC}(-71.6 \%), \mathrm{MR}(-55.2 \%), \mathrm{MF}(-69.6 \%)$, PL $(-64.6 \%)$ and ZF $(-51.8 \%)$. These reductions could be more pronounced if we consider that similar wind speeds between LRD and LDD occurred. As shown in the previous section, significantly lower wind speeds are recorded in BA and MR during LDD. According Richmond-Bryant et al. (2018), there is a negative correlation between wind speed

TABLE I. DAILY AVERAGE VALUES AND STANDARD DEVIATION OF CHEMICAL POLLUTANTS LEVELS DURING THE LONG-TERM LOCKDOWN REFERENCE PERIOD (LRD, $15^{\text {th }}$ MARCH TO $15^{\text {th }}$ APRIL 2010-2019) VS DAILY AVERAGE VALUES DURING THE 2020 LOCKDOWN PERIOD (LDD, $15^{\text {th }}$ MARCH TO $15^{\text {th }}$ APRIL 2020) IN BADAJOZ (BA), CÁCERES (CC), MÉRIDA (MR), MONFRAGÜE (MF), PLASENCIA (PL) AND ZAFRA (ZF).

\begin{tabular}{|c|c|c|c|c|}
\hline \multirow{2}{*}{$\begin{array}{l}\text { Location / } \\
\text { air pollutant }\end{array}$} & \multirow{2}{*}{ LRD } & \multirow{2}{*}{ LDD } & \multicolumn{2}{|c|}{ LDD-LRD } \\
\hline & & & Absolute & $\%$ \\
\hline \multicolumn{5}{|c|}{ BA } \\
\hline $\mathrm{NO}_{2}\left(\mu \mathrm{g} / \mathrm{m}^{3}\right)$ & $8.1 \pm 3.6$ & $4.0 \pm 1.6$ & -4.1 & -50.4 \\
\hline $\mathrm{O}_{3}\left(\mu \mathrm{g} / \mathrm{m}^{3}\right)$ & $59.6 \pm 10.9$ & $53.7 \pm 10.2$ & -5.9 & -9.9 \\
\hline $\operatorname{BTX}\left(\mu \mathrm{g} / \mathrm{m}^{3}\right)$ & $0.9 \pm 0.3$ & $0.2 \pm 0.1$ & -0.6 & -75.4 \\
\hline \multicolumn{5}{|c|}{$\mathrm{CC}$} \\
\hline $\mathrm{NO}_{2}\left(\mu \mathrm{g} / \mathrm{m}^{3}\right)$ & $7.6 \pm 2.9$ & $2.1 \pm 0.8$ & -5.4 & -71.6 \\
\hline $\mathrm{O}_{3}\left(\mu \mathrm{g} / \mathrm{m}^{3}\right)$ & $65.3 \pm 11.1$ & $60.6 \pm 11.5$ & -4.8 & -7.3 \\
\hline $\operatorname{BTX}\left(\mu \mathrm{g} / \mathrm{m}^{3}\right)$ & $1.1 \pm 0.5$ & $0.3 \pm 0.1$ & -0.8 & -75.0 \\
\hline \multicolumn{5}{|c|}{ MR } \\
\hline $\mathrm{NO}_{2}\left(\mu \mathrm{g} / \mathrm{m}^{3}\right)$ & $7.3 \pm 2.6$ & $3.3 \pm 1.3$ & -4.0 & -55.2 \\
\hline $\mathrm{O}_{3}\left(\mu \mathrm{g} / \mathrm{m}^{3}\right)$ & $64.0 \pm 10.0$ & $58.0 \pm 10.0$ & -6.1 & -9.5 \\
\hline $\operatorname{BTX}\left(\mu \mathrm{g} / \mathrm{m}^{3}\right)$ & $1.1 \pm 0.8$ & $0.9 \pm 0.3$ & -0.1 & -12.5 \\
\hline \multicolumn{5}{|c|}{ MF } \\
\hline $\mathrm{NO}_{2}\left(\mu \mathrm{g} / \mathrm{m}^{3}\right)$ & $5.1 \pm 1.5$ & $1.5 \pm 0.7$ & -3.5 & -69.6 \\
\hline $\mathrm{O}_{3}\left(\mu \mathrm{g} / \mathrm{m}^{3}\right)$ & $72.5 \pm 10.9$ & $59.3 \pm 11.7$ & -13.2 & -18.2 \\
\hline $\operatorname{BTX}\left(\mu \mathrm{g} / \mathrm{m}^{3}\right)$ & $0.7 \pm 0.3$ & $0.7 \pm 0.1$ & -0.0 & -4.4 \\
\hline \multicolumn{5}{|c|}{ PL } \\
\hline $\mathrm{NO}_{2}\left(\mu \mathrm{g} / \mathrm{m}^{3}\right)$ & $7.4 \pm 3.5$ & $2.6 \pm 1.0$ & -4.8 & -64.6 \\
\hline $\mathrm{O}_{3}\left(\mu \mathrm{g} / \mathrm{m}^{3}\right)$ & $79.4 \pm 11.6$ & $64.1 \pm 10.0$ & -15.2 & -19.2 \\
\hline \multicolumn{5}{|c|}{$\mathbf{Z F}$} \\
\hline $\mathrm{NO}_{2}\left(\mu \mathrm{g} / \mathrm{m}^{3}\right)$ & $5.0 \pm 1.9$ & $2.4 \pm 1.0$ & -2.6 & -51.8 \\
\hline $\mathrm{O}_{3}\left(\mu \mathrm{g} / \mathrm{m}^{3}\right)$ & $83.7 \pm 9.1$ & $68.0 \pm 8.1$ & -15.7 & -18.8 \\
\hline $\operatorname{BTX}\left(\mu \mathrm{g} / \mathrm{m}^{3}\right)$ & $0.9 \pm 0.4$ & $0.9 \pm 0.2$ & -0.0 & -0.2 \\
\hline
\end{tabular}

and $\mathrm{NO}_{2}$ concentration $(\mathrm{r}=-0.53)$ with an influence of $27.7 \%$, so the reductions in BA and MR could be approximately $-70 \%$.

Similar reductions of $\mathrm{NO}_{2}$ levels have been observed in large cities in Europe, such as Barcelona $(-47.0 \%)$ (Tobías et al. 2020), Valencia (-69.0\%) and Rome (-45.6\%) (Sicard et al. 2020), where $\mathrm{NO}_{2}$ levels are usually higher than those recorded in the relatively small cities of Extremadura studied in this work (e.g. $5.9 \mu \mathrm{g} / \mathrm{m}^{3}$ is the daily average concentration of $\mathrm{NO}_{2}$ during the period 2010-2019 in BA).

Figure 3 provides a closer look to the evolution of daily means of $\mathrm{NO}_{2}$ levels measured at the air quality monitoring units of Extremadura during the immediate 2020 pre-lockdown period (PLD) and during the 2020 lockdown period (LDD), orange line, together with the daily averages and variability ranges of the 2010-2019 long-term pre-lockdown and lockdown reference period (PRD and LRD), blue line. It is remarkable the decrease of $\mathrm{NO}_{2}$ levels from $14^{\text {th }}$ March 2020, starting day of the lockdown in BA, CC, MR, PL and ZF, deviating from the 2010-2019 LRD time series. Notably, in the case of the Monfragüe National Park, $\mathrm{MF}$ (Fig. 3D), $\mathrm{NO}_{2}$ levels are lower during the PLD+LDD period $\left(14^{\text {th }}\right.$ February $-15^{\text {th }}$ April 2020) compared to the reference period (PRD+LRD), but no change is observed due to lockdown (from PLD to LDD). So, the difference observed between LDD and LRD (Fig. 2) could be due to an overall historical evolution of $\mathrm{NO}_{2}$ levels in the MF area. Therefore, the lockdown did not affect $\mathrm{NO}_{2}$ levels in $\mathrm{MF}$, as expected in a remote natural environment far from anthropogenic emission derived from traffic. Neither during the reference period nor lockdown, there have been exceedances of the hourly limit value $\left(200 \mu \mathrm{g} / \mathrm{m}^{3}\right.$, hourly average) for the protection of human health (European Commission 2008) at any of the air quality surveillance units, as is usual in the study area.

The reduction in $\mathrm{NO}_{2}$ levels in ambient air observed in the monitoring units of BA, CC, MR, PL and $\mathrm{ZF}$ are probably due to the decrease in road traffic during the confinement period, since internal combustion engines, especially diesel and to a lesser extent gasoline, are the most relevant source of nitrogen oxides in urban ambient air (Nakada and Urban 2020 and Tobías et al. 2020). We did not observe the decrease in the National Park of Monfragüe, where the unit is in an environment where traffic is always absent.

\section{Ozone $\left(\mathrm{O}_{3}\right)$}

Figure 4 presents the evolution of $\mathrm{O}_{3}$ levels during the 2010-2019 lockdown reference period (LRD) 

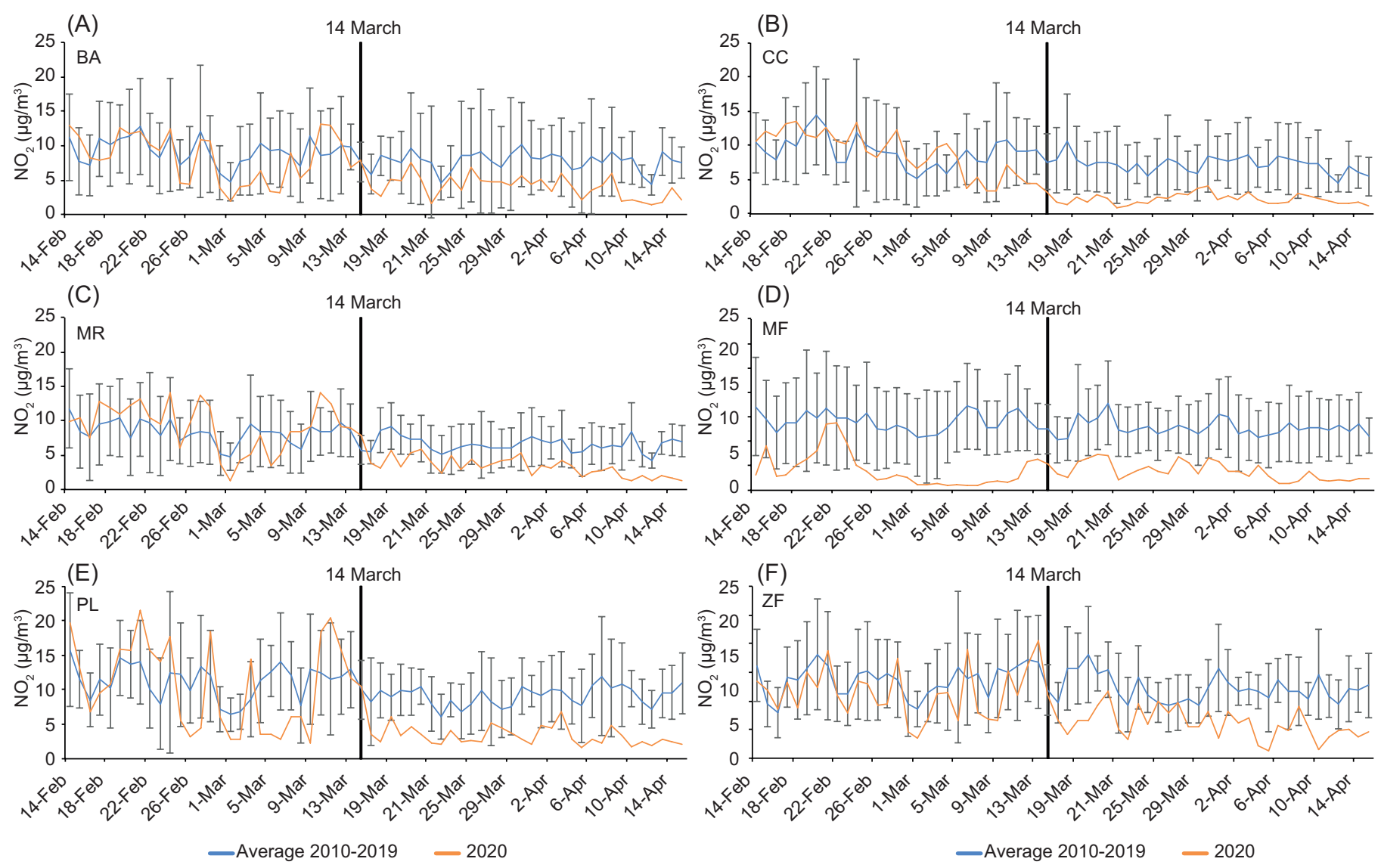

Fig. 3. Evolution of average daily concentrations of $\mathrm{NO}_{2}$ during PLD (14 $4^{\text {th }}$ February to $14^{\text {th }}$ March 2020) and LDD (15 $5^{\text {th }}$ March to $15^{\text {th }}$ April 2020$)$, with PRD (14 ${ }^{\text {th }}$ February to $14^{\text {th }}$ March $\left.2010-2019\right)$ and LRD (15 ${ }^{\text {th }}$ March to $15^{\text {th }}$ April $\left.2010-2019\right)$.

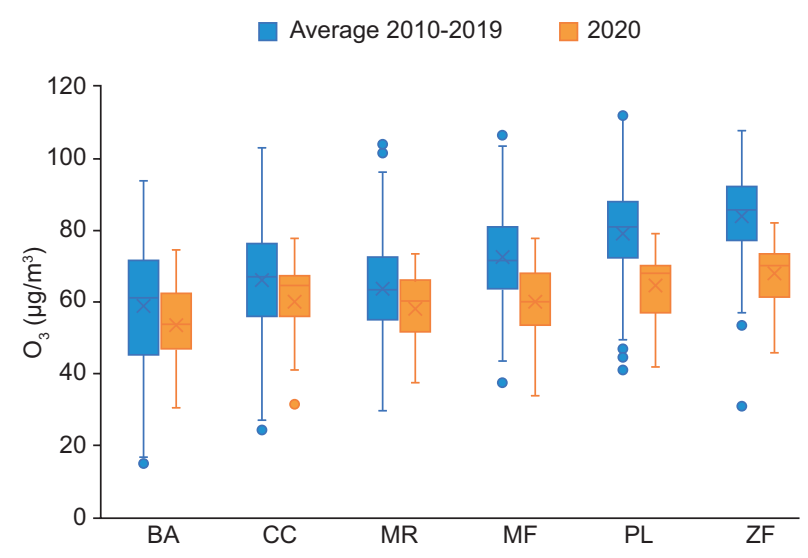

Fig. 4. Distribution of daily averages of $\mathrm{O}_{3}$ during $\operatorname{LDD}\left(15^{\text {th }}\right.$ March to $15^{\text {th }}$ April 2020) and LRD (15 ${ }^{\text {th }}$ March to $15^{\text {th }}$ April 2010-2019).

and 2020 lockdown period (LDD). Table I shows the absolute and percentage variations. Concentrations of $\mathrm{O}_{3}$ experienced a more significant decrease $(\mathrm{p}<0.0001)$ in small towns like PL $(-19.2 \%), \mathrm{ZF}$ $(-18.8 \%)$ and also at MF National Park $(-18.2 \%)$. The decrease is less pronounced $(\mathrm{p}<0.01)$ at larger cities such as BA $(-9.9 \%)$ and MR $(-9.5 \%)$ (Table I). Figure 5 presents the evolution of daily means of $\mathrm{O}_{3}$ levels measured at the air quality monitoring units of Extremadura during the immediate 2020 pre-lockdown period (PLD) and during the 2020 lockdown period (LDD), together with the daily averages of the 2010-2019 long-term pre-lockdown and lockdown reference period (PRD and LRD). We observed slight decreases in the concentration of $\mathrm{O}_{3}$ during the lockdown period in $\mathrm{BA}, \mathrm{CC}, \mathrm{MR}$ and $\mathrm{MF}$, while the decreases in PL and ZF lower levels of $\mathrm{O}_{3}$ are observed throughout the period $\left(14^{\text {th }}\right.$ February $15^{\text {th }}$ April 2020) compared to the daily averages for the period 2010-2019 (Fig. 5E and F). Also, figure 5 shows a more pronounced decrease of $\mathrm{O}_{3}$ from $6^{\text {th }}$ April to $14^{\text {th }}$ April 2020 in all locations, probably due to a significant change in weather conditions (cloudy and rainy days). 

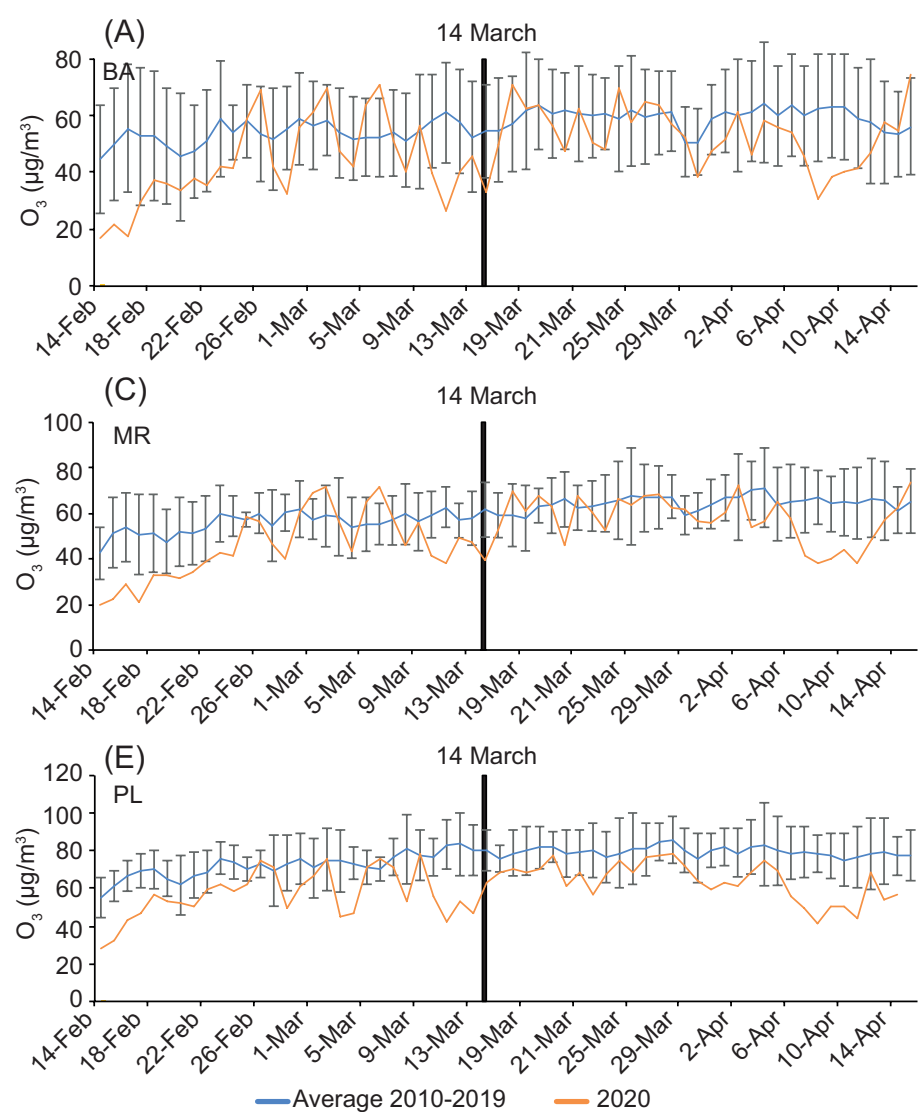
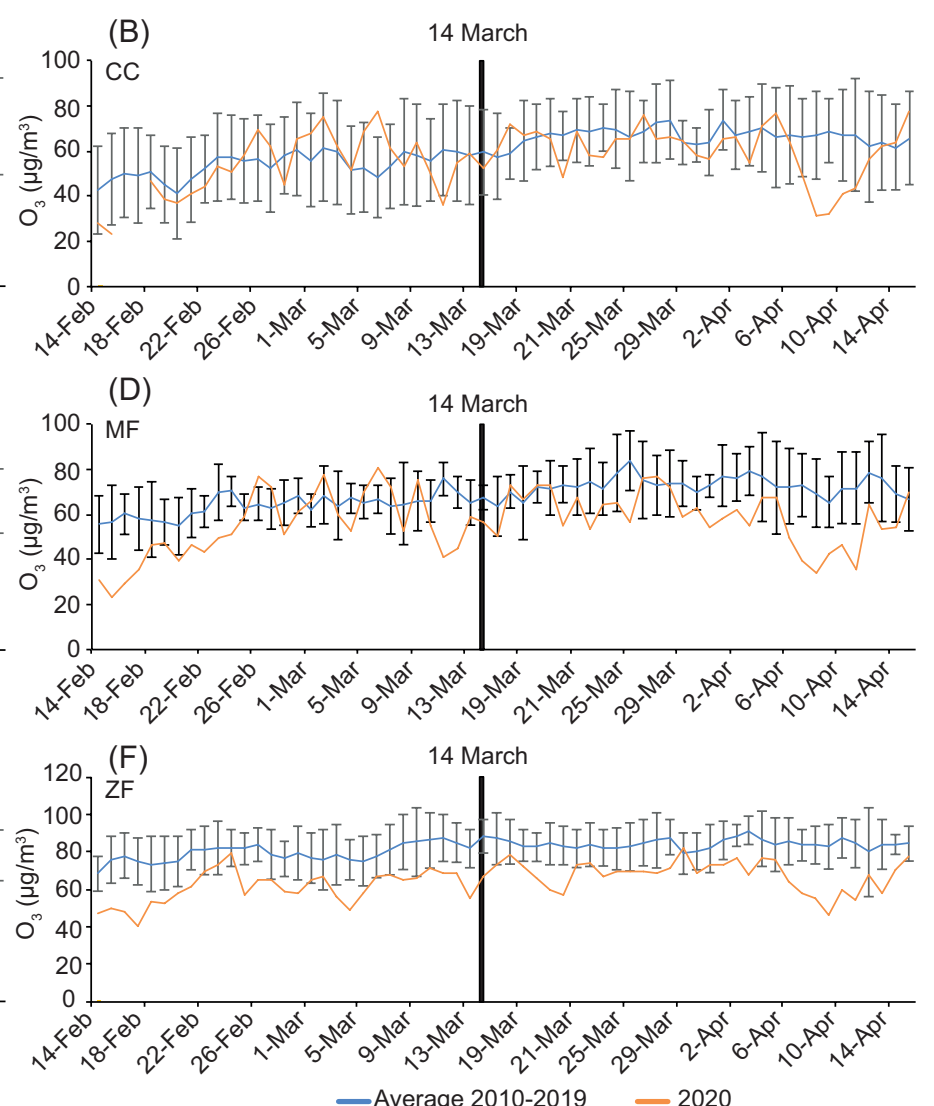

Fig. 5. Evolution of average daily concentrations of $\mathrm{O}_{3}$ during PLD $\left(14^{\text {th }}\right.$ February to $14^{\text {th }}$ March 2020$)$ and LDD (15 ${ }^{\text {th }}$ March to $15^{\text {th }}$ April 2020$)$, with PRD (14 $4^{\text {th }}$ February to $14^{\text {th }}$ March 2010-2019) and LRD (15 $5^{\text {th }}$ March to $15^{\text {th }}$ April 2010-2019).

$\mathrm{O}_{3}$ is a secondary pollutant whose atmospheric chemistry is complex and highly variable depending on the physical and chemical characteristics of the environment. It is particularly affected by temperature and relative proportions between precursors, especially nitrogen oxides (NOx) and volatile organic compounds (VOCs). Other studies have reported increases in ozone concentrations during the COVID-19 lockdown period (Nakada and Urban 2020, Sharma et al. 2020, Sicard et al. 2020 and Tobías et al. 2020). All these works have used data from air quality surveillance stations located in urban and industrial environments of major cities such as Barcelona, Nice, Turin, Rome, Gaya, Sao Paulo. These highly polluted urban areas present a low VOC-NOx ratio due to high concentrations of NOx. Therefore, under VOC limited conditions, reduction in $\mathrm{VOC}$ concentrations reduces the formation of $\mathrm{O}_{3}$, while a reduction in NOx concentrations increases the formation of $\mathrm{O}_{3}$ (Beekmann and Vautard 2010 and Anav et al. 2019). However, in low polluted suburban and rural areas such as those studied in the present work, $\mathrm{O}_{3}$ generation is mainly limited by the concentration of NOx available in the environment, so a reduction in the concentration of NOx has promoted a decrease of $\mathrm{O}_{3}$ levels, while a reduction in VOC levels has no impact on $\mathrm{O}_{3}$ concentrations (Monks et al. 2015, Colman 2017, Anav et al. 2019). This phenomenon is probably the reason for the decreased levels of $\mathrm{O}_{3}$ observed in the study region during the lockdown. Besides, another important factor is the change in weather conditions during the last week of lockdown (precipitation, high relative humidity and low solar radiation), because this weather scenario is less favourable for the photochemical formation of tropospheric ozone (He et al. 2017).

\section{Benzene, toluene and xylene (BTX)}

Figure 6 shows the comparison of BTX concentrations during the 2010-2019 lockdown reference period (LRD) and 2020 lockdown period (LDD). Table I shows the absolute and percentage changes. In BA and CC, BTX levels are significantly lower $(-75.4$ and $-75.0 \%$, respectively) respect to the data 


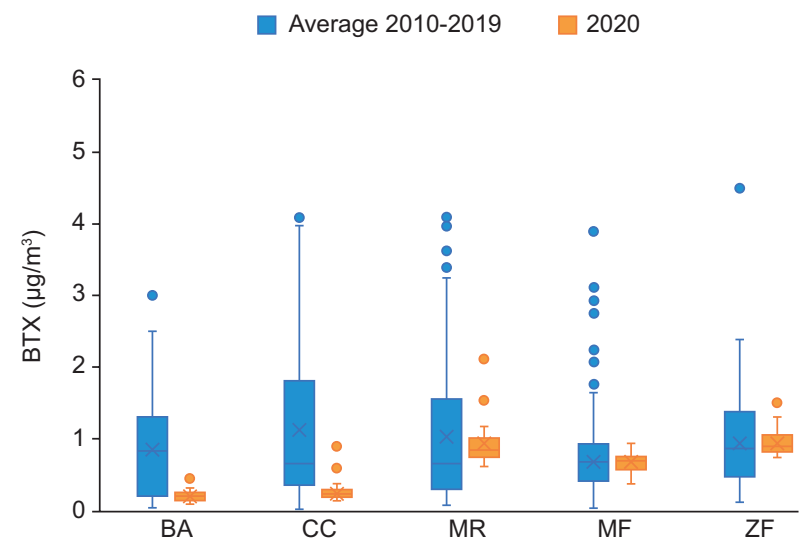

Fig. 6. Distribution of daily averages of BTX during LDD $\left(15^{\text {th }}\right.$ March to $15^{\text {th }}$ April 2020) and LRD (15 $5^{\text {th }}$ March to $15^{\text {th }}$ April 2010-2019). BTX data from the PL monitoring station was not available. for previous years $(2010-2019)(p<0.0001)$. Since VOCs, including benzene, are mainly produced by road traffic and other incomplete combustion processes (Collivignarelli et al. 2020). Figure 7 shows the evolution of the daily means of BTX concentrations measured at the air quality monitoring units of Extremadura during the immediate 2020 pre-lockdown period (PLD) and during 2020 lockdown period (LDD), together with the daily means and variability ranges of the 2010-2019 long-term pre-lockdown and lockdown reference period (PRD and LRD). In BA and $\mathrm{CC}$, lockdown did not affect to BTX levels, due to lower values measured throughout the period $\left(14^{\text {th }}\right.$ February $-15^{\text {th }}$ April 2020) compared to the reference period 2010-2019 (Fig. 7A and B). In the locations studied in this work, BTX concentrations are usually very variable and low (minimum $0.04 \mu \mathrm{g} / \mathrm{m}^{3}$ and maximum $4.8 \mu / \mathrm{gm}^{3}$, detection limit $0.03 \mu \mathrm{g} / \mathrm{m}^{3}$ ), close to the detection limit, making it difficult to
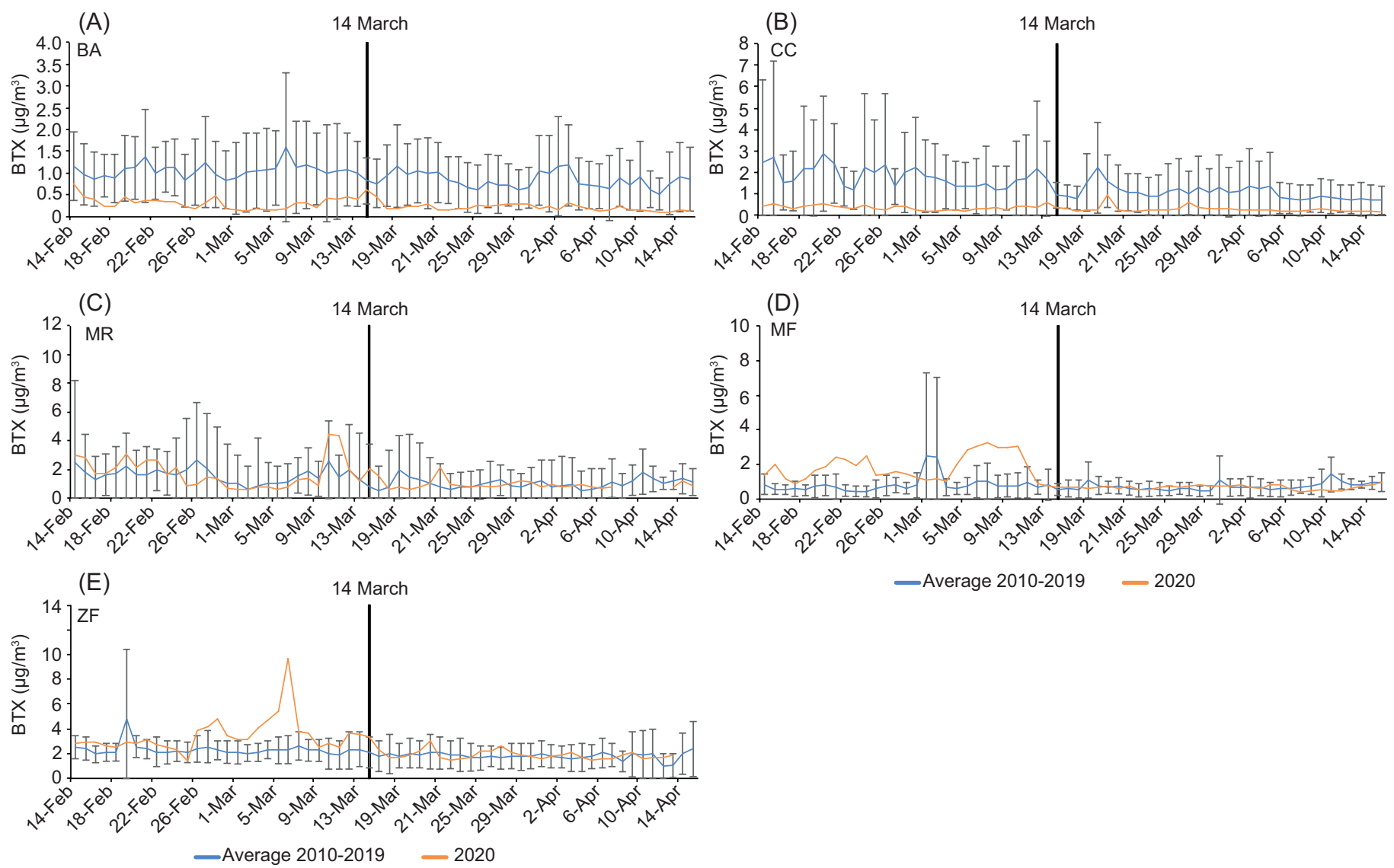

—Average 2010-2019 — 2020

Fig. 7. Evolution of average daily concentrations of BTX during PLD (14 ${ }^{\text {th }}$ February to $14^{\text {th }}$ March 2020$)$ and LDD (15 $5^{\text {th }}$ March to $15^{\text {th }}$ April 2020$)$, with PRD (14 ${ }^{\text {th }}$ February to $14^{\text {th }}$ March 2010-2019) and LRD (15 ${ }^{\text {th }}$ March to $15^{\text {th }}$ April 2010-2019). BTX data from the PL monitoring station was not available. 
interpret the trends. Therefore, it is difficult to evaluate the specific impact of confinement on BTX concentrations in the study region.

\section{CONCLUSIONS}

The impact of the lockdown measures derived from the alarm state by COVID-19 has positively influenced the air quality of Extremadura. During the first month of lockdown $\left(15^{\text {th }}\right.$ March to $15^{\text {th }}$ April 2020) a very significant decrease in $\mathrm{NO}_{2}$ levels has been observed respect to the same period 2010-2019, reaching an average decrease of $\sim 60 \%$ if the BA CC, MR, PL and ZF data are combined. The most likely reason behind this phenomenon is the reduction of traffic levels in Extremadura, the primary source of nitrogen oxides. We measured less pronounced decreases of $\mathrm{O}_{3}(\sim 13 \%)$ in BA, MR and MF, probably related to the reduction of $\mathrm{NO}_{2}$ concentrations in NOx limited environments and the change in weather variables during the lockdown. However, ozone is significantly affected by the variability of a diverse set of anthropogenic and natural sources, by associated atmospheric chemistry, as well as by long-distance transport. Therefore, it would be necessary to study it more thoroughly, considering all these variables to establish more relevant conclusions. BTX levels during confinement have high variability and very low values, showing no clear trend before and after the lockdown. The effects of lockdown on air quality are an excellent opportunity to study the contribution of the different sources of emission of primary pollutants and to evaluate the behavior of secondary pollutants in the atmosphere of cities, and contributing to test public policies to improve air quality.

\section{ACKNOWLEDGMENTS}

We acknowledge the air quality surveillance network of Extremadura (REPICA, project 1855999FD022), Spain, partially financed by European Union Funds for Regional Development (FEDER).

\section{REFERENCES}

Anav A., De Marco A., Friedlingstein P., Savi F., Sicard P., Sitch S., Vitale M. and Paoletti E. (2019). Growing season extension affects ozone uptake by European forests. Sci. Total Environ. 669, 1043-1052. https:// doi.org/10.1016/j.scitotenv.2019.03.020
Beekmann M. and Vautard R. (2010). A modelling study of photochemical regimes over Europe: Robustness and variability. Atmos. Chem. Phys. 10, 10067-10084. https://doi.org/10.5194/acp-10-10067-2010

Cerrato-Alvarez M., Núñez-Corchero M., Miró-Rodríguez C. and Pinilla-Gil E. (2020). Synoptic circulation patterns and local sources associated to high concentrations of tropospheric ozone in rural and suburban areas in southwestern Spain. Air Qual. Atmos. Hlth. 13, 97-108. https://doi.org/10.1007/s11869-019-00774-w

Collivignarelli M.C., Abbà A., Bertanza G., Pedrazzani R., Ricciardi P. and Carnevale Miino M. (2020). Lockdown for CoViD-2019 in Milan: What are the effects on air quality? Sci. Total Environ. 732, 139280. https:// doi.org/10.1016/j.scitotenv.2020.139280

Colman E.G. (2017). Contaminación amosférica: cinética y mecanismos de la fotodegradación de compuestos orgánicos biogénicos. Tesis de Doctorado. Departamento de Fisicoquímica, Universidad Nacional de Córdoba. Córdoba, Argentina, 190 pp.

European Commission (2008). Directive 2008/50/EC of the European Parliament and of the Council on ambient air quality and cleaner air for Europe. Official Journal of the European Union. 21 of May 2008.

European Committee for Standardization (2012a). Ambient air. Standard method for the measurement of the concentration of nitrogen dioxide and nitrogen monoxide by chemiluminescence. European Standard. 22 of August 2012.

European Committee for Standardization (2012b). Ambient air. Standard method for the measurement of the concentration of ozone by ultraviolet photometry. European Standard. 22 of August 2012.

European Committee for Standardization (2015). Ambient air. Standard method for the measurement of benzene concentrations - Part 3: Automated pumped sampling with in situ gas chromatrography. European Standard. 18 of November 2015.

Global Change Data Lab (2020). Coronavirus Disease (COVD-19) - Statistics and Research. Oxford Martin School, The University of Oxford. URL https://ourworldindata.org/coronavirus/ 12/11/2020.

He J., Gong S., Yu Y., Yu L., Wu L., Mao H., Song C., Zhao S., Liu H., Li X. and Li R. (2017). Air pollution characteristics and their relation to meteorological conditions during 2014-2015 in major Chinese cities. Environ. Pollut. 223, 484-496. https://doi.org/10.1016/j. envpol.2017.01.050

Hopkins J. (2020). John Hopkins University of Medicine. Coronavirus Research Center. https://coronavirus.jhu. edu/map.html 12/11/2020.

Ministerio de la Presidencia, Relaciones con las Cortes y Memoria Democrática (2020a). Real Decreto 
463/2020, de 14 de marzo, por el que se declara el estado de alarma para la gestión de la situación de crisis sanitaria ocasionada por el COVID-19. Boletín Oficial del Estado. 14 de Marzo de 2020.

Ministerio de la Presidencia, Relaciones con las Cortes y Memoria Democrática (2020b). Real Decreto-ley 10/2020, de 29 de marzo, por el que se regula un permiso retribuido recuperable para las personas trabajadoras por cuenta ajena que no presten servicios esenciales. Boletín Oficial del Estado. 29 de Marzo de 2020.

Monks P.S., Archibald A.T., Colette A., Cooper O., Coyle M., Derwent R., Fowler D., Granier C., Law K.S., Mills G.E., Stevenson D.S., Tarasova O., Thouret V., Von Schneidemesser E., Sommariva R., Wild O. and Williams M.L. (2015). Tropospheric ozone and its precursors from the urban to the global scale from air quality to short-lived climate forcer. Atmos. Chem. Phys. 15, 8889-8973. https://doi.org/10.5194/acp-15-8889-2015

Muhammad S., Long X. and Salman M. (2020). COVID-19 pandemic and environmental pollution: A blessing in disguise?. Sci. Total Environ. 728, 138820. https://doi.org/10.1016/j.scitotenv.2020.138820

Nakada L.Y.K. and Urban R.C. (2020). COVID-19 pandemic: Impacts on the air quality during the partial lockdown in São Paulo state, Brazil. Sci. Total Environ. 730, 139087. https://doi.org/10.1016/j.scitotenv.2020.139087

Querol X., Pérez N., Reche C., Ealo M., Ripoll A., Tur J., Pandolfi M., Pey J., Salvador P., Moreno T. and Alastuey A. (2019). African dust and air quality over Spain: Is it only dust that matters? Sci. Total Environ. 686, 737-752. https://doi.org/10.1016/j.scitotenv.2019.05.349
Richmond-Bryant J., Snyder M.G., Owen R.C. and Kimbrough S. (2018). Factors associated with $\mathrm{NO}_{2}$ and NOx concentration gradients near a highway. Atmos. Environ. 174, 214-226. https://doi.org/10.1016/j. atmosenv.2017.11.026

Saadat S., Rawtani D. and Hussain C.M. (2020). Environmental perspective of COVID-19. Sci. Total Environ. 728, 138870. https://doi.org/10.1016/j.scitotenv.2020.138870

Sánchez-Martín J.M., Blas-Morato R. and Rengifo-Gallego J.I. (2019). The dehesas of Extremadura, Spain: A potential for socio-economic development based on agritourism activities. Forests 10 (8), 620. https://doi. org/10.3390/f10080620

Sharma S., Zhang M., Anshika, Gao J., Zhang H. and Kota S.H. (2020). Effect of restricted emissions during COVID-19 on air quality in India. Sci. Total Environ. 728, 138878. https://doi.org/10.1016/j.scitotenv.2020.138878

Sicard P., De Marco A., Agathokleous E., Feng Z., Xu X., Paoletti E., Rodriguez J.J.D., and Calatayud V. (2020). Amplified ozone pollution in cities during the COVID-19 lockdown. Sci. Total Environ. 735, 139542. https://doi.org/10.1016/j.scitotenv.2020.139542

Tobías A., Carnerero C., Reche C., Massagué J., Via M., Minguillón M.C., Alastuey A. and Querol X. (2020). Changes in air quality during the lockdown in Barcelona (Spain) one month into the SARS-CoV-2 epidemic. Sci. Total Environ. 726, 138540. https://doi. org/10.1016/j.scitotenv.2020.138540 


\section{SUPPLEMENTARY MATERIAL}

TABLE SI. DAILY AVERAGE VALUES AND STANDARD DEVIATION OF METEOROLOGICAL PARAMETERS DURING THE LONG-TERM LOCKDOWN REFERENCE PERIOD (LRD, 15th MARCH TO 15th April 2010-2019) VS DAILY AVERAGE VALUES DURING THE 2020 LOCKDOWN PERIOD (LDD, 15TH MARCH TO 15TH APRIL 2020) IN BADAJOZ (BA), CÁCERES (CC), MÉRIDA (MR), MONFRAGÜE (MF), PLASENCIA (PL) AND ZAFRA (ZF).

\begin{tabular}{|c|c|c|c|c|}
\hline \multirow{2}{*}{$\begin{array}{l}\text { Location / } \\
\text { meteorological parameters }\end{array}$} & \multirow[t]{2}{*}{ LRD } & \multirow[t]{2}{*}{ LDD } & \multicolumn{2}{|c|}{ LDD-LRD } \\
\hline & & & Absolute & $\%$ \\
\hline \multicolumn{5}{|c|}{ BA } \\
\hline Temperature $\left({ }^{\circ} \mathrm{C}\right)$ & $13.9 \pm 2.7$ & $13.9 \pm 2.4$ & 0.0 & +0.2 \\
\hline Solar radiation $\left(\mathrm{W} \mathrm{m}^{-2}\right)$ & $212.3 \pm 133.6$ & $146.8 \pm 114.7$ & -65.5 & -30.8 \\
\hline Relative humidity (\%) & $70.1 \pm 10.1$ & $78.0 \pm 8.9$ & 7.9 & +11.3 \\
\hline Wind speed $\left(\mathrm{m} \mathrm{s}^{-1}\right)$ & $2.6 \pm 1.0$ & $2.0 \pm 1.0$ & -0.6 & -24.4 \\
\hline Rainfall (mm) & $1.4 \pm 3.2$ & $4.8 \pm 7.9$ & 3.4 & +240.2 \\
\hline \multicolumn{5}{|c|}{$\mathrm{CC}$} \\
\hline Temperature $\left({ }^{\circ} \mathrm{C}\right)$ & $13.3 \pm 3.1$ & $12.8 \pm 2.5$ & -0.5 & -3.8 \\
\hline Solar radiation $\left(\mathrm{W} \mathrm{m}^{-2}\right)$ & $230.8 \pm 135.4$ & $157.0 \pm 116.2$ & -73.8 & -32.0 \\
\hline Relative humidity (\%) & $64.6 \pm 12.4$ & $76.1 \pm 10.2$ & 11.5 & +17.8 \\
\hline Wind speed $\left(\mathrm{m} \mathrm{s}^{-1}\right)$ & $3.0 \pm 1.1$ & $2.8 \pm 1.2$ & -0.2 & -5.3 \\
\hline Rainfall (mm) & $1.8 \pm 3.1$ & $4.5 \pm 6.9$ & 2.7 & +156.3 \\
\hline \multicolumn{5}{|c|}{ MR } \\
\hline Temperature $\left({ }^{\circ} \mathrm{C}\right)$ & $14.1 \pm 2.9$ & $14.1 \pm 2.6$ & 0.0 & +0.2 \\
\hline Solar radiation $\left(\mathrm{W} \mathrm{m}^{-2}\right)$ & - & - & - & - \\
\hline Relative humidity (\%) & $67.9 \pm 11.9$ & $74.1 \pm 11.1$ & 6.2 & +9.2 \\
\hline Wind speed $\left(\mathrm{m} \mathrm{s}^{-1}\right)$ & $2.5 \pm 1.0$ & $2.0 \pm 1.0$ & -0.5 & -20.0 \\
\hline Rainfall (mm) & $1.2 \pm 2.4$ & $3.5 \pm 6.7$ & 2.3 & +202.9 \\
\hline \multicolumn{5}{|c|}{ MF } \\
\hline Temperature $\left({ }^{\circ} \mathrm{C}\right)$ & $13.2 \pm 3.3$ & $12.6 \pm 0.7$ & -0.6 & -4.4 \\
\hline Solar radiation (W m-2) & - & - & - & - \\
\hline Relative humidity (\%) & $64.3 \pm 15.6$ & $72.2 \pm 11.5$ & 7.9 & +12.3 \\
\hline Wind speed (m s-1) & $3.2 \pm 1.4$ & $3.5 \pm 1.9$ & 0.3 & +8.7 \\
\hline Rainfall (mm) & $2.3 \pm 4.3$ & $3.6 \pm 6.0$ & 1.3 & +55.0 \\
\hline \multicolumn{5}{|c|}{ PL } \\
\hline Temperature $\left({ }^{\circ} \mathrm{C}\right)$ & $13.0 \pm 2.9$ & $13.4 \pm 2.4$ & 0.4 & +3.3 \\
\hline Solar radiation $\left(\mathrm{W} \mathrm{m}^{-2}\right)$ & - & - & - & - \\
\hline Relative humidity (\%) & $57.2 \pm 13.5$ & $70.0 \pm 10.4$ & 12.8 & +22.4 \\
\hline Wind speed $\left(\mathrm{m} \mathrm{s}^{-1}\right)$ & $1.8 \pm 0.7$ & $1.5 \pm 0.7$ & -0.3 & -17.7 \\
\hline Rainfall (mm) & $2.2 \pm 4.2$ & $3.2 \pm 6.4$ & 1.0 & +46.8 \\
\hline \multicolumn{5}{|c|}{$\mathrm{ZF}$} \\
\hline Temperature $\left({ }^{\circ} \mathrm{C}\right)$ & $12.8 \pm 2.9$ & $12.7 \pm 2.4$ & -0.1 & -0.4 \\
\hline Solar radiation $\left(\mathrm{W} \mathrm{m}^{-2}\right)$ & - & - & - & - \\
\hline Relative humidity (\%) & $68.0 \pm 10.7$ & $76.2 \pm 6.4$ & 8.2 & +12.1 \\
\hline Wind speed $\left(\mathrm{m} \mathrm{s}^{-1}\right)$ & $2.7 \pm 1.0$ & $2.3 \pm 1.2$ & -0.4 & -14.2 \\
\hline Rainfall (mm) & $1.6 \pm 3.2$ & $3.2 \pm 6.6$ & 1.6 & +104.3 \\
\hline
\end{tabular}

